\title{
THE EFFECT OF CURRENT AND RELEVANT INFORMATION SOURCES ON THE USE OF LIBRARY SERVICES IN THE UNIVERSITY LIBRARIES IN THE SOUTHEASTERN NIGERIA
}

\author{
A. D. UGAH
}

\begin{abstract}
The study investigated the effect of current and relevant information sources on the use of library services in the university libraries in the southeast of Nigeria. Two objectives, two research questions and two hypotheses guided this study. The population for this study was made up of 12,500 registered users out of which a sample of 2000 was taken using proportionate sampling technique. Data were collected using the questionnaire and were analyzed through the use of frequency tabulation and percentages. The hypotheses were tested using statistical method of Pearson Product Moment Correlation (PPMC) analysis and Multiple Regression Analysis with the use of computer programme of Statistical Package for Social Science (SPSS)version10.0. The hypotheses testing were conducted at 0.05 level of significance $(p<0.05)$ for rejection or retention. The currency and relevance of information sources therefore have significant relationship with the use of library services. Recommended adequate funding to acquire current and relevant information sources as well as the provision of ICT and Internet facilities to encourage the use of library services.
\end{abstract}

KEY WORDS: Information sources, currency, relevance, use of library, ICT, Internet

\section{BACKGROUND TO THE STUDY}

Universities are important agents for national development in any nation. Through their programme of teaching, learning, research and community service, universities produce the requisite high-level manpower for the engineering of social, economic and political progress of any nation. Their research activities result in national self-discovery and awareness, which ensure that planning and development are based on truth and rational policies. One of the foundations on which this national development can be actualized is manpower development to which higher education is primarily tied, and that explains why certain percentage of the national budget is tied to education at the tertiary level. The functions of universities are spelt out in the laws establishing them. Their functions include teaching, research, conservation, transmission and advancement of knowledge and public service. The tripartite functions of any university is to conserve knowledge, transmit or disseminate knowledge through teaching, conferences, seminars, publications and to advance knowledge through research, the provision of intellectual leadership, and the development of human resources for meeting the manpower needs. To fulfill these essential goals, the university library must necessarily have the benefit of adequate information sources of the heritage of mankind's accumulated knowledge and wisdom. These information sources must be current and relevant.

\section{The Purpose and Objectives of the Study}

The purpose of this study was to investigate the information sources variables and the use of library services in the university libraries in the southeast of Nigeria. The specific objectives are:

1. To determine the effect of current information sources on the use of library services.

A. D. Ugah, University Library, Michael Okpara University of Agriculture, Umudike, PMB 7267, Umuahia, Abia State 
2. To asses the effect of relevant information sources on the use of library services.

\section{Research Questions}

The following research questions guided the study:

1. What is the effect of current information sources on the use of library services?

2. What is the effect of relevant information sources on the use of library services?

\section{Hypotheses}

The following null hypotheses were tested.

1. The currency of information source has no significant effect on the use of library services.

2. The relevance of information sources has no significant effect on the use of library services.

\section{LITERATURE REVIEW}

The issue of currency of information sources and the use of libraries in Nigerian universities had been in focus for the past fifteen years. In her library use study Awojobi (2004), reported low patronage of a university library, which was blamed mostly on paucity of current information sources. Oyediran- Tidings (2004) reported similar findings at Yaba College of Technology, Lagos. However, in a similar study conducted by lyoro (2004), the serials collection of University of Ibadan was adjudged relatively current by the respondents. It was revealed that $81(32 \%)$ of the respondents, considered the serial holdings of the library very current, 133 $(52 \%)$ respondents considered them current and $42(16 \%)$ respondents claimed that the Serial holdings were not current but have retrospective values. In other words, current information sources resulted in the use of the library.

Jam (1992) identified lack of relevant information sources to be one of the problems facing library users and has accounted for the low use of library services. Although the study was not carried out in a university, this finding is a pointer to similar situations in university libraries. In another study by Osinulu and Balogun (2003) 18(10.71\%) of respondents, indicated irrelevant information sources, as one they face in using the library .The library stock did not meet their requirements. Antwi (1987) quoted in Ekoja (1994) studied the relevance and adequacy of Bauchi State Library Service.
The findings revealed that $43 . \%$ of the respondents did not find the information sources relevant and could not use the library effectively. Malumfashi (1988) conducted similar a study of Kano State Library Service, got similar result and made similar conclusions. The situation is even more serious in academic libraries as was reported by Osinulu (2003), whose study was on a university library. Akande (2003) yet in a similar study, reported that $31.8 \%$ of the respondents indicated lack of textbooks of relevance to their studies as their major inhibition to their use of library and its services.

\section{METHOD}

The ex-post-facto research design of the survey method was used. The population for this study consisted of library-registered users estimated to be 12,500 in the universities under study. University libraries include: Abia State University (ABSU), Uturu; Michael Okpara University of Agriculture (MUOA), Umudike; Anambra State University of Science and Technology (ASUST) lhiala; Nnamdi Azikiwe University (NAU), Awka; Imo State University Owerri (IMSU), Federal University of Technology, Owerri (FUTO), University of Nigeria, Nsukka (UNN), and Enugu State University of Science and Technology (ESUST).

The sample size was selected using proportionate stratified random sampling method. The main instrument for data collection for this study was a questionnaire. Using the Likert-type scale modified model, to make five negative statements on each variable, the respondents were requested to tick their level of agreement or disagreement whether they strongly agree, agree, disagree or strongly disagree. The instrument went through validation reliability test process.

Copies of the questionnaire were distributed to all the eight university libraries. The two main statistical techniques-descriptive and inferential--- were put to use. The data collected were analyzed through the use of frequency tabulation and percentages to answer research questions. The hypotheses were tested using statistical method of Pearson Product Moment Correlation (PPMC) analysis and Multiple Regression Analysis with the use of computer programme of Statistical Package for Social Science (SPSS) version10.0. Using correlation analysis as inferential method in this study, it determined whether the observed correlation between variables as determined from the 
sample could be generalized to the population. In this case, a p-value was calculated and used to accept or reject the null hypotheses. If the null hypothesis is accepted, then there is no need obtaining a regression to predict the value of the independent value.

All the hypotheses testing were conducted at 0.05 level of significance $(p<0.05)$ for rejection or retention. The 0.05 level of significance (alpha) was chosen as studies have shown that it is fairly reliable at this level to accept or reject a hypothesis.

\section{DATA ANALYSES}

Out of the 2000 copies of questionnaires distributed, 1508 of them were returned, given $75.4 \%$ return rate and all found useful for analysis. 393(36.06\%) were staff while1115 (73.94\%) were students. The male respondents were $863(57.23 \%)$ while the female respondents were $645(42.77 \%)$. This shows a fair representation of the respondents in terms of gender. Those in the age range 16-25, topped the table with $1043(69.16 \%)$, this is followed by those in the age range of 26-35 with $313(20.76 \%)$, then $36-45$ with $109(7.23 \%)$ and so on. The fact that those in the age range 16-25 is not surprising because they constitute the bulk of the students and library users, which is normal in any university.

In terms of qualification, those with Senior Secondary School Certificate were the majority with $1005(64.64 \%)$, followed by those with Master's degree, 161(10.68\%) and then Bachelor's degree holders. That those with Senior Secondary Certificate are not in doubt because the basic entry requirement for admission into first degree programmes is SSCE or its equivalent. Since majority of the teaching and administrative staff possess masters degree and the universities run doctoral degree programmes, it is not surprising that those with the masters degree certificate came second with $161(10.68 \%)$. Then followed by those with the first degree certificates came third with 153 (10.15\%).

Frequency of the respondents' use of library services

Table 1: Users Responses on the frequency of use of library services

\begin{tabular}{|c|c|c|c|c|c|c|c|c|c|c|}
\hline \multicolumn{3}{|c|}{ Use of Library Construct } & \multicolumn{8}{|c|}{ Responses } \\
\hline & & & SA & A & $\begin{array}{l}\text { Agree } \\
\text { Total } \\
\text { and } P e\end{array}$ & $\begin{array}{l}t t^{\prime} s \\
\text { ntage }\end{array}$ & D & SD & $\begin{array}{l}\text { Disa } \\
\text { Tota } \\
\text { Perc }\end{array}$ & $\begin{array}{l}\text { ments' } \\
\text { re and } \\
\text { ge. }\end{array}$ \\
\hline \multicolumn{2}{|r|}{$\begin{array}{l}\text { Use of Library } \\
\text { Constructs }\end{array}$} & & $\bar{F}$ & $\mathrm{~F}$ & $\bar{F}$ & $\%$ & $\bar{F}$ & $\mathrm{~F}$ & $\mathrm{~F}$ & $\%$ \\
\hline$a$ & Daily & 1508 & 168 & 444 & 612 & 40.6 & 446 & 450 & 896 & 59.4 \\
\hline $\mathrm{b}$ & $\begin{array}{l}4-5 \text { times a } \\
\text { week }\end{array}$ & 1508 & 168 & 448 & 616 & 40.8 & 298 & 594 & 892 & 59.1 \\
\hline C & $\begin{array}{l}1-3 \text { times a } \\
\text { week }\end{array}$ & 1508 & 446 & 150 & 596 & 39.6 & 744 & 168 & 892 & 60.5 \\
\hline $\mathrm{d}$ & $\begin{array}{l}1-3 \text { times a } \\
\text { month }\end{array}$ & 1508 & 320 & 296 & 616 & 40.8 & 594 & 298 & 892 & 59.1 \\
\hline e & $\begin{array}{l}\text { Less than once } \\
\text { a month }\end{array}$ & 1508 & 168 & 445 & 613 & 40.7 & 448 & 446 & 894 & 59.3 \\
\hline
\end{tabular}

As shown in table 1 , the index of daily use was scored $168(11 \%)$ strongly agreed and $444(29.4 \%)$ agreed, with a total score of $612(40.6 \%)$ who agreed that their use of library services was on daily basis. Meanwhile,
446(29.6\%) strongly disagreed and $450(29.8 \%)$ disagreed, with a total score of $896(59.4 \%)$ who disagreed on using the library services on daily basis. The frequency of use of 4-5 times a week was scored 168 (11.1\%) and 448((29.7\%), 
making a total of $616(40.8 \%)$, who agreed that the frequency of their libraries was 4-5 times a week.298 (19.8\%), and 594(39.4 \%,) totaling $892(59.1 \%)$, disagreed that their frequency of use of their libraries is $4-5$ times a week. The frequency of 1-3 times a week of using the library was scored $446(29.6 \%)$ and $150(10.0 \%)$, making a total agreement score of $596(39.5 \%)$. Meanwhile, those who disagreed were scored $744(49.3 \%)$ and 168 (11.1) totalling912 (60.5 $\%$ ). The frequency of 1-3 times a month was scored $320(21.2 \%)$ and 296(19.6\%), making a total of $616(40.8 \%)$ agreement. Meanwhile, 594 $(39.5 \%)$ and $298(19.8 \%)$ making a total of 892 $(59.1 \%)$ disagreed. The index of less than once a month was scored $168(11.1 \%)$ and 446 $(29.6 \%)$, totaling $614(40.7 \%)$, who agreed using the library less than once a month. while, 448 $(29.7 \%)$ and $446(29.6 \%)$ making a total frequency of $894(59.3 \%)$ disagreed on using the library on less once a month basis. The implication of the analysis was that the library services were used.

Currency of Information Sources

Table 2: Users Responses on the currency of Information Sources in the University libraries in the southeast Nigeria

\begin{tabular}{|c|c|c|c|c|c|c|c|c|c|c|}
\hline \multirow{2}{*}{\multicolumn{3}{|c|}{$\begin{array}{l}\text { Currency of Information Sources } \\
\text { Construct }\end{array}$}} & \multicolumn{8}{|c|}{ Response } \\
\hline & & & \multirow{2}{*}{$\begin{array}{l}\mathrm{SA} \\
\\
\mathrm{F} \\
\end{array}$} & \multirow[t]{2}{*}{$\begin{array}{l}\mathrm{A} \\
\mathrm{F}\end{array}$} & \multicolumn{2}{|c|}{$\begin{array}{l}\text { Agreement's } \\
\text { Total score and } \\
\text { Percentage }\end{array}$} & \multirow[t]{2}{*}{$\begin{array}{l}\mathrm{D} \\
\mathrm{F}\end{array}$} & \multirow[t]{2}{*}{$\begin{array}{l}\text { SD } \\
\mathrm{F}\end{array}$} & \multicolumn{2}{|c|}{$\begin{array}{l}\text { Disagreement' } \\
\text { s Total Score } \\
\text { and } \\
\text { Percentage }\end{array}$} \\
\hline & & & & & $\mathrm{F}$ & $\%$ & & & $\mathrm{~F}$ & $\%$ \\
\hline A & Low & 1508 & 616 & 446 & 1062 & 70.4 & 402 & 44 & 446 & 29.6 \\
\hline$B$ & $\begin{array}{l}\text { Unsatisfactory In my } \\
\text { discipline }\end{array}$ & 1508 & 764 & 448 & 1212 & 80.3 & 198 & 98 & 296 & 19.6 \\
\hline $\mathrm{C}$ & $\begin{array}{l}\text { My use of the library does } \\
\text { not depend on the currency } \\
\text { of Information Sources }\end{array}$ & 1508 & 198 & 98 & 296 & 19.6 & 894 & $\begin{array}{l}31 \\
8\end{array}$ & 1212 & 80.4 \\
\hline D & $\begin{array}{l}\text { Does not satisfy my use of } \\
\text { library services }\end{array}$ & 1508 & 892 & 170 & 1062 & 70.4 & 298 & $\begin{array}{l}14 \\
8\end{array}$ & 446 & 29.6 \\
\hline $\bar{E}$ & $\begin{array}{l}\text { Does not Influence my use } \\
\text { of library services }\end{array}$ & 1508 & 168 & 148 & 316 & 20.9 & 148 & $\begin{array}{l}10 \\
44\end{array}$ & 1192 & 79.0 \\
\hline
\end{tabular}

As shown in table 2, lack of current information sources was scored $616(40.8 \%)$ for 'strongly agree' and 446 (29.6\%) for 'agree' totaling $1062(70.4 \%)$ agreement. On the other hand, $402(26.7 \%)$ strongly disagreed and $44(2.9 \%)$ disagreed, making a disagreement total of $446(29.6 \%)$.

Currency of information sources in respondents' disciplines not satisfactory was scored $764(50.7 \%)$ for 'strongly agree' and $448(29.7 \%)$ for 'agree', making an agreement total of $1212(80.3 \%)$. On the other, $296(19.6 \%)$ $196(13.0 \%)$ disagreed and $98(6.5 \%)$ strongly disagreed. The use of library not depending on the currency of information sources was scored 198(13.0\%) for 'strongly agree' and $98(6.5 \%)$ for 'agree', making agreement total score of $296(19.6 \%)$. On the other hand,
894(59.3\%) strongly disagreed and $318(21.1 \%)$ disagreed, making disagreement total score of $1212(80.3 \%)$. In other words, 1212(80.3\%) agreed that their use of library services is dependent on the currency of information sources. The currency of information sources not encouraging the use of library services was scored $148(9.6 \%)$ for 'strongly agree' and 298 $(19.8 \%)$ for 'agree', making agreements total of 446(29.6\%). However, 892(59.2\%) strongly disagreed and $170(11.3 \%)$ disagreed, with a total of $1062(70.4 \%)$. In other words, 1062 $(70.4 \%)$, agreed that the currency of information sources encouraged the use of library services. The currency of information sources not influencing the use of library services was scored $168(11.2 \%)$ for 'strongly agree' and $148(9.8 \%)$ for 'agree', with agreement total of $316(20.9 \%)$. 
Meanwhile, $148(9.8 \%)$ strongly disagreed and $1044(62.2 \%)$ disagreed, with disagreement total of $1192(79.0 \%)$. In other words, $79.0 \%$ agreed that the currency of information sources influenced their use of library services. The
Librarian as information provider should acquire current information sources to encourage the use of library services.

Relevance of Information Sources

Table 3: Users Responses on the Relevance of Information Sources in the southeast university libraries Nigeria

\begin{tabular}{|c|c|c|c|c|c|c|c|c|c|c|}
\hline \multirow{2}{*}{\multicolumn{3}{|c|}{$\begin{array}{l}\text { Relevance of Information } \\
\text { Sources Construct }\end{array}$}} & \multicolumn{8}{|c|}{ Response } \\
\hline & & & \multirow{2}{*}{$\begin{array}{l}\text { SA } \\
\\
\mathrm{F}\end{array}$} & \multirow{2}{*}{$\begin{array}{l}\mathrm{A} \\
\mathrm{F}\end{array}$} & \multicolumn{2}{|c|}{$\begin{array}{l}\text { Agreement's } \\
\text { Total score } \\
\text { and } \\
\text { Percentage }\end{array}$} & \multirow{2}{*}{$\begin{array}{l}\mathrm{D} \\
\\
\mathrm{F} \\
\end{array}$} & \multirow{2}{*}{$\begin{array}{l}\text { SD } \\
\\
\mathrm{F} \\
\end{array}$} & \multicolumn{2}{|c|}{$\begin{array}{l}\text { Disagreement' } \\
\text { s Total Score } \\
\text { and } \\
\text { Percentage }\end{array}$} \\
\hline & & & & & $F$ & $\%$ & & & $F$ & $\%$ \\
\hline a & Not relevant & 1508 & 466 & 746 & 1212 & 80.4 & 148 & 148 & 296 & 19.6 \\
\hline b & $\begin{array}{l}\text { Not relevant in my } \\
\text { discipline }\end{array}$ & 1508 & 912 & 298 & 1210 & 80.3 & 298 & 0 & 298 & 19.8 \\
\hline C & $\begin{array}{l}\text { My use of the } \\
\text { library does not } \\
\text { depend on the } \\
\text { relevance of } \\
\text { Information } \\
\text { Sources }\end{array}$ & 1508 & 148 & 148 & 296 & 19.6 & 478 & 594 & 1072 & 71.1 \\
\hline $\bar{d}$ & $\begin{array}{l}\text { Does not satisfy } \\
\text { my use of library } \\
\text { services }\end{array}$ & 1508 & 466 & 746 & 1212 & 80.4 & 296 & 0 & 296 & 19.6 \\
\hline e & $\begin{array}{l}\text { Does not Influence } \\
\text { my use of library } \\
\text { services }\end{array}$ & 1508 & 150 & 148 & 298 & 19.8 & 464 & 746 & 1192 & 80.3 \\
\hline
\end{tabular}

As shown in table 3 , information sources not being relevant were scored 466 (30.9\%) for 'strongly agree' and $746(49.5 \%)$ for 'agree', with agreement total of $1212(80.4 \%)$. On the other hand, $148(9.8 \%)$ strongly disagreed and 148 $(9.8 \%)$ disagreed, with a total of $296(19.6 \%)$ disagreement. The relevance of information sources not satisfactory in respondents' various disciplines were scored $912(60.5 \%)$ for 'strongly agree' and 298(19.8\%) for 'agree', with agreements total of $1210(80.3 \%)$. Meanwhile $298(19.8 \%)$ disagreed. The use of library services not depending on the relevance of information sources was scored 148 (9.8\%) for 'strongly agree' and148 (9.8\%) for 'agree', with agreements total of $296(19.6 \%)$. Meanwhile,
478(31.7\%) strongly disagreed and 594 (39.4\%) disagreed, with disagreement total of 1072 $(71.1 \%)$. The relevance of information sources not satisfying the respondents' use of the library services was scored $466 \quad(30.9 \%)$ and $746(49.5 \%)$, with agreements total of $1210(80.3 \%)$. The relevance of information sources not influencing the use of library services was scored $150(10.0 \%)$ and 148 $(9.8 \%)$ with agreement total of 198 (19.8\%). Meanwhile, $464(30.8 \%)$ strongly disagreed and $746(49.5 \%)$ disagreed with a total of 1192 $(79.0 \%)$ that disagreed. 
H01. The current information sources has no significant effect with the use of Library services.
To test this hypothesis, the data collected were analyzed using PPMC analysis. The result obtained is presented in table 4 below

Table 4: PPMC Analysis of relationship between the current information sources (X3) and the use of library services $(Y)$

\begin{tabular}{|l|l|l|l|l|l|l|l|l|c|}
\hline $\mathrm{N}$ & $\sum \mathrm{Y}$ & $\sum \mathrm{X} 1$ & $\sum \mathrm{Y}$ & $\sum \mathrm{X} 1$ & $\sum \mathrm{YX} 1$ & $\mathrm{r}$-value & $\mathrm{P}$ & $\mathrm{df}$ & Decision \\
\hline 1508 & 20705 & 17743 & 308427 & 226943 & 245256 & 0.664 & 0.05 & $\begin{array}{l}150 \\
6\end{array}$ & $\mathrm{~S}$ \\
\hline
\end{tabular}

$P \leq 0.05, S=$ Significant, $d f=1506$, Critical value $=0.165$

The obtained r-value was 0.664 . The value was tested for significance by comparing it with the critical value of 0.165 at 0.05 with 1506 degree of freedom. The obtained value was greater than the critical r-value. Since the calculated r-value of 0.664 is greater than the critical value at 0.165 , the tested null hypothesis is rejected. The currency of information sources therefore, has significant relationship with the use of library services in the university libraries in the Southeast Nigeria.

HO2. The relevance of information sources has no significant relationship with the use of library services.

To test this hypothesis, the data collected were analyzed using PPMC analysis. The result obtained is presented in table 5 below

Table 5; PPMC Analysis of relationship between the relevance of information sources (X4) and the use

\begin{tabular}{|l|c|l|l|l|l|l|l|c|c|}
\hline $\mathrm{N}$ & $\sum \mathrm{Y}$ & $\sum \mathrm{X} 2$ & $\sum \mathrm{Y}$ & $\sum \mathrm{X} 2$ & $\sum \mathrm{YX} 2$ & $\mathrm{r}-$ value & $\mathrm{P}$ & $\mathrm{df}$ & Decision \\
\hline 1508 & 20705 & 17693 & 308430 & 225811 & 2444489 & 0.674 & 0.05 & 1506 & $\mathrm{~S}$ \\
\hline
\end{tabular}

$\mathrm{P} \leq 0.05, \mathrm{~S}=$ Significant, $\mathrm{df}=1506$, Critical value $=0.165$.

The obtained r-value was 0.674 . The value was tested for Significance by comparing it with the critical value of 0.165 at 0.05 with 1506 degree of freedom. The obtained value was greater than the critical $r$-value. Since the calculated r-value of 0.674 is greater than the critical value at 0.165 , the tested null hypothesis is rejected. The relevance of information sources therefore, has significant relationship with the use of library services in the university libraries in the southeast Nigeria.

\section{DISCUSSION OF FINDINGS}

The main objective of this study was to determine the effect of current and relevant of information sources on the use of library services. On the basis of the independent variables currency and relevance of information sources, two objectives, two research questions and two hypotheses were formulated to investigate the dependent variables of use of library services in the Universities in the Southeast of Nigeria. The findings of the investigations based on the literature reviewed, research questions and hypotheses formed the basis of the following discussion.
The null hypothesis was rejected. There is significant relationship between the currency of information sources and the use of library services has $80.3 \%$ dependence on the currency of information sources and the currency of information sources has $79.0 \%$ influence on the use of library services.

These findings agree with those of Awojobi (2004) and lyoro (2004) and Oyediran Tidings (2004). Awojobi (2004) Oyediran-Tidings (2004) and lyoro (2004) reported similar findings in their various studies that covered Olabisi Onabanjo University Library, Ago-Iwoye, and Yaba college of Technology, Lagos and University of Ibadan, respectively.

On the concept of relevance of information sources, the null hypothesis was rejected. There is significant relationship between the relevance of information sources and the use of library services. The result of this study reveals that relationship. This relationship is positive as the use of library services has $71.1 \%$ dependence on relevance of information sources and the relevance of information sources has $80.3 \%$ influence on the use of library services. 
This finding agrees with a similar finding by Oyediran (1998) who established that information sources are not relevant, thereby make the use of library services frustrating and problematic. It also agreed with another finding by Jam (1992) who identified lack of relevant sources of information to be one of the problems facing library user. Osinulu and Balogun (2003) and Antwi (1987) made similar findings.

\section{CONCLUSION AND RECOMMENDATIONS}

The findings from the study also reveal significant relationships between the variables of currency and relevance of information sources and the use of library services, and that the currency and relevance of information to a large extent influence the use of library services.

Based on these findings, it is recommended that the libraries should always acquire the most current information sources, and weed out the outdated ones as funds are made available.

The researcher also recommends that the university libraries should always liaise with the users so that the sources that are relevant to their needs can be acquired.

The provision of ICT and Internet facilities is a necessity to ensure that users have access to current information sources. The basis for these implementation of these recommendations is adequate funding of the university libraries.

The libraries should on their own explore other external sources of information, relevant to the needs of their users through inter-library cooperation.

\section{REFERENCES}

Akande, S. O., 2003. Patterns of first year students' use of a university library: a survey of University of Ibadan. Lagos Journal of Library and Information Science. 2, (1): 23-27.

Antwi, I.K., 1987. The relevance and adequacy of Bauchi State library services: an appraisal by users. Nigerian Library and Information Science Review 7, (2):9.

Awojobi, E., 2004. Determinants of library use by lecturers of science and college of agricultural science, Olabisi. Onabanjo University, Ago-Iwoye Nigeria. Nigerian libraries. 38, (1): 34-47.
Ekoja, I. I., 1994. An appraisal of usersatisfaction with the services of Sokoto State library services. Lagos Librarian.15: 15-64.

Ekoja, I. I., 1995. Contemporary issues in collection development programmes in Nigerian University Libraries. International Information and Library Review. 2, (27) (4): 333-343.

Iyoro, A. O., 2004. Serial availability, accessibility and utilization: Perceptions of in-training information professionals in a Nigerian university. The Nigerian Library Link 11, (2): 66-71.

Jam, Zauwa, 1992. The information needs of academic staff in a non-university technologically based tertiary institutions in Benue state. Nigerian Libraries 25\&26, $(1-4): 21-35$.

Malumfashi, M.U., 1988. Survey of users' satisfaction of services and collection of Kano State Library Services Board. The Communicator, III: 71- 85.

Osinulu, L. F., 2003. Library use in Ogun State University: a survey. Gateway Library Journal 6, (2): 81-87.

Osinulu, L. F. and Balogun, F., 2005. Effectiveness of reference services to Faculty members: a case study of Olabisi Onbanjo University, Ago-Iwoye. Gateway Library Journal. 6, (2): 98-105.

Oyediran, Abo, 1998. Nigerian university libraries in the $21^{\text {st }}$ century: the future begins with the present In:Salisu, T.M and Olanlokun, SO CULNU proceedings of Ibadan and Ekpoma, 1992 and 1994 : Lagos: CULNU.

Oyediran-Tidings, S., 2004. Information needs and seeking behavior of library users, result from Yaba College of Technology, Lagos: Lagos Journal of Library and Information Science 2, (2):77-88. 